Cuadernos de Filología Clásica. Estudios Latinos

ISSN: 1131-9062

http://dx.doi.org/10.5209/cfcl.73011

\title{
Los «Apuntes para un curso de filología latina» de Canalejas en la filología española de la Restauración ${ }^{1}$
}

\author{
Miguel Á. Perdomo-Batista ${ }^{2}$
}

Recibido: 11 de mayo de 2020 / Aceptado: 23 de noviembre de 2020

Resumen. En este trabajo me propongo examinar los "Apuntes para un curso de literatura latina" publicados por José Canalejas Méndez entre 1874 y 1876. El análisis mostrará cómo la obra se inserta en la tradición de la centuria anterior, pero es capaz también de superarla para conformar una síntesis particular en el contexto en que se está conformando, también, la escuela de filología española. En este sentido, debe recordarse que la Historiografía de la Literatura Latina nace unida a la de la Literatura Española. Desde el punto de vista metodológico, se formulan algunas propuestas para el análisis de los textos con los que se construye la Historiografía de la Literatura Latina.

Palabras clave: Canalejas; Literatura Latina; filología española, Restauración.

\section{[en] The «Notes for a Latin Philology Course» of Canalejas in the Spanish Philology of the Restoration}

\begin{abstract}
In this work I propose to examine the "Apuntes para un curso de literatura latina" published by José Canalejas Méndez between 1874 and 1876. The analysis will show how the work is inserted in the tradition of the previous century, but it is also capable of surpassing it to conform a particular synthesis in the context in which the school of Spanish philology is also being formed. In this sense, it should be remembered that the Historiography of Latin Literature is born together with that of Spanish Literature. From the methodological point of view, some proposals are formulated for the analysis of the texts with which the Historiography of Latin Literature is constructed.
\end{abstract}

Keywords: Canalejas; Latin literature; Spanish philology, Restauración.

Sumario: 1. Introducción. 2. Marco teórico. 3. Materiales y metodología. 4. Discusión y resultados. 5. Conclusiones. 6. Referencias bibliográficas.

Cómo citar: Perdomo-Batista, M.Á., «Los “Apuntes para un curso de filología latina” de Canalejas en la filología española de la Restauración», Cuad. Filol. Clás. Estud. Lat. 40.2 (2020), 327-344.

\footnotetext{
1 Alguna de las ideas contenidas en este artículo fue expuesta en una comunicación titulada «Las ideas lingüísticas de Canalejas en sus "Apuntes para un curso de literatura latina", presentada en el IX Congreso de la SELat, ORBIS LATINVS, celebrado en Granada del 10 al 17 de mayo de 2019. Las actas de ese congreso aún no han sido editadas.

2 Universidad de Las Palmas de Gran Canaria.

Correo electrónico: miguel.perdomo@ulpgc.es
} 


\section{Introducción}

Me propongo examinar los Apuntes para un curso de literatura latina, publicados por José Canalejas Méndez entre 1874 y 1876. Tal análisis se efectúa bajo el supuesto de que las conclusiones pueden ser interesantes no solo para la Historiografía de la Literatura Latina, sino también para la historia de la escuela de filología española, y particularmente de sus orígenes. En este sentido, y como señala Dan Munteanu $(2017,62)$, debemos recordar que «la lingüística histórica y la historia literaria (en el sentido actual) nacen aproximadamente en mismo período (especialmente en el campo de la filología románica)». Sostengo que es posible advertir significativos puntos de contacto entre la obra de Canalejas y las ideas de Menéndez Pidal.

Pero antes de pasar a los siguientes apartados, creo que no será inútil una oportuna contextualización de la obra y de su autor. Como se sabe, José Canalejas Méndez (1854-1912) fue uno de los personajes más relevantes de la España decimonónica. Se licenció en Filosofía y Letras en la Universidad Central de Madrid en 1871 y al año siguiente en Derecho para a continuación doctorarse. Durante su formación asistió como alumno a la cátedra de A. A. Camús ${ }^{3}$. Durante varios años fue auxiliar en la cátedra de su tío Francisco de Paula (cátedra de Principios generales de Literatura y Literatura española), tarea que desempeña hasta 1872. Fruto de esta colaboración es la publicación en 1873 del Programa de un curso de Principios generales de Literatura. En 1874 y 1876 publico sendos tomos de sus Apuntes para un curso de literatura latina. En 1877 opositó a la cátedra de literatura española en la Universidad Central, ganada finalmente por Menéndez Pelayo. En 1880 fue elegido diputado liberal por Soria y comenzó una extraordinaria carrera política que lo llevaría a dirigir varios ministerios y finalmente a la presidencia del gobierno entre 1010 y 1912. El 12 de noviembre de 1912, mientras miraba el escaparate de una librería de Puerta del Sol, falleció en un atentado perpetrado por el anarquista Manuel Pardinas.

\section{Marco teórico}

Creo que la Historiografía de la Literatura Latina, para la que García Jurado (2008b, 181 y 197) señala un carácter ancilar respecto de la aportaciones extranjeras y aun de las tradiciones hispanas anteriores (desde el siglo XVIII hasta el $\mathrm{XX}$ ) evolucionó en relación con la Historiografía de la Literatura Española, cuyos orígenes se remontan al siglo XVIII (Perdomo-Batista 2020), y, en el contexto de lo que se conocería como «edad de plata de la cultura española» (García Jurado, 2008a, 177), ambas contribuyeron a conformar la escuela de filología española. Así pues, nuestra perspectiva no será solamente la de la Historiografía de la Literatura Latina ${ }^{4}$, sino también la de la historiografía de las ideas lingüísticas en España, y esta pretende ser precisamente nuestra aportación. Por lo demás, y como

Alfredo Adolfo Camús es una figura importante para entender la evolución de la Historiografía de la Literatura Latina de finales del siglo XVIII e inicios de la Restauración. Francisco García Jurado se ha ocupado de él en varios y oportunos trabajos $\left(2005^{\mathrm{a}}, 2005 \mathrm{~b}, 2008 \mathrm{a}, 2008 \mathrm{~b}\right)$. Ha dirigido también algún TFM en la UCM (Salvador Gimeno, 2016). García Jurado fue IP del proyecto de investigación nacional "Legado Alfredo Adolfo Camús en la Biblioteca del Marqués de Valdecilla (FFI 2013-41976).

4 En este sentido, y para el siglo XVIII, puede verse Javier Espino 2003. 
ha señalado Fernández Corte (2004), no debemos pasar por alto que el nacimiento como disciplina de la Historia de la Literatura Latina es inseparable de las instituciones educativas del naciente estado liberal, en el que tiene el propósito de formar una conciencia nacional. Tratándose de Canalejas, y por razones obvias, tampoco podemos perder de vista este aspecto.

Por otra parte, tampoco debemos olvidar que algunos de los temas y argumentos más importantes de la Historiografía de la Literatura Latina de la época, como la adscripción de los autores hispano-latinos o la discusión sobre el estilo de Séneca y Lucano, surgen en la segunda mitad del siglo XVIII en el contexto de las polémicas en reivindicación de las aportaciones españolas a la cultura europea en respuesta a la polémica suscitada por Mason de Morvilliers y, en el ámbito literario, por los abates italianos Bettinelli y Tiraboschi ${ }^{5}$, que acusaban a los autores españoles de haber corrompido la literatura española en al Antigüedad y en el siglo XVII. Las opiniones de Bettinelli y Tiraboschi también fueron impugnadas por algunos españoles que residían en Italia. Tal es el caso del P. Juan Andrés y los abates Tomás Serrano y Javier Llampillas. Finalmente, en este ámbito es inexcusable recordar el trabajo de los hermanos Rodríguez Mohedano, porque las cuatrocientas dos páginas de la Disertación apologética, que ocupan todo el tomo VII de su Historia literaria, son una impugnación en tono apologético de las ideas expuestas por los abates italianos.

Así es que la cuestión tiene al menos tres dimensiones: una epistemológica, relacionada con los orígenes de la Historiografía de la Literatura Latina en relación con la Historiografía de la Literatura Española y con las tendencias de la filología europea, todo ello como sustrato de lo que luego será la escuela de filología española. Otra institucional, ya sea en relación con las instituciones del Antiguo Régimen en el siglo XVIII (bibliotecas, archivos, puestos de cronista oficial) o los ámbitos educativos del incipiente estado liberal (enseñanza media y universitaria, programas y manuales universitarios). Una tercera de carácter más ideológico y quizá político: la discusión sobre la aportación de la cultura española a la europea, que luego daría lugar al debate sobre la ciencia española a finales del siglo XIX. Iniciado por el krausista Gumersindo de Azcárate, en el debate participó también Menéndez Pelayo, uno de cuyos alumnos fue precisamente Menéndez Pidal, que en 1899 ganó la Cátedra de Filología comparada del latín y del castellano en la Universidad Central de Madrid.

La polémica sobre la ciencia española fue provocada por Gumersindo de Azcára$t^{6}{ }^{6}$, que había afirmado que la actitud del estado podía ahogar el desarrollo de la actividad científica, como sucediera en España durante los últimos siglos. Menéndez y Pelayo no dejó pasar la cuestión, y, estimulado por su maestro, Gumersindo Laverde, escribió una réplica a Azcárate. Terció después en la disputa el académico Manuel de la Revilla, al que respondió don Marcelino?.

Según Ladero Quesada (1996, 238, 39), en la obra de don Marcelino la indagación ya tópica sobre las causas de la decadencia de España cede su lugar a la pre-

Saverio Bettinelli había publicado en 1769 Dell'entusiasmo delle belle arti (Milano: Giuseppe Galeazzi), y en 1775 Del Risorgimento d'Italia negli studi e nelle arti e ne' costumi dopo il mille (Bassano: Remondini). Girolamo Tiraboschi venía editando desde 1772 su Storia della letteratura italiana (Modena: Società tipografica, $1772-1782,11 \mathrm{v}$.$) .$

El self-government y la monarquía doctrinaria. Madrid: Librerías de A. de San Martín, 1877.

Seguimos el relato de Pedro Sáinz Rodríguez $(1962,122)$. Todos los artículos mencionados fueron publicados en los tomos VII y VIII de Revista Contemporánea. Sobre estas cuestiones puede verse García Camarero E. y E., 1970. 
gunta sobre el ser de España, que debe ser revitalizado, y que se halla en las formas políticas y religiosas de los siglos XVI y XVII. Para don Marcelino, el problema del ser de España era el problema de un país que se hallaba «entre el deterioro y la restauración de su ser profundo». Pero lo que nos interesa recordar ahora en relación con la obra y el pensamiento de Canalejas, es que los planteamientos de Menéndez y Pelayo serían extremados luego por los regeneracionistas. Recordemos, además, que según José Luis Abellán (1979, I, 51 y ss.), la gran aportación de don Marcelino a la historiografía española (La ciencia española, Historia de los heterodoxos españoles e Historia de las ideas estéticas en España) fue en gran parte una respuesta a la polémica sobre la ciencia española.

Para realizar el examen que me propongo será preciso presentar el enfoque y las posibles perspectivas del análisis, aspecto este último que abordaremos en el apartado dedicado a la metodología.

Desde el punto de vista historiográfico, soy partidario del enfoque contextualita y hermenéutico que en los últimos años parece haberse ido imponiendo en el ámbito de la Historiografía de la Lingüística ${ }^{8}$. Para esta perspectiva historiográfica contextualita y hermenéutica es preciso superar el tradicional análisis apriorístico que trata de explicar los hechos adscribiendo las obras a las diferentes escuelas y tendencias. Este planteamiento se ha revelado insuficiente, particularmente para la historiografía anterior a la etapa «moderna» (Laborda Gil, 1981). Por nuestra parte, y a propósito de la filología del siglo XVIII, hemos comprobado (Perdomo-Batista 2020) que las nuevas tendencias se incardinan con las tradicionales (actividades de los bibliotecarios, archiveros, cronistas oficiales, historiadores del derecho y de la religión) muy a menudo al amparo de las instituciones de la Monarquía. Suponemos que esta perspectiva es aplicable también a la siguiente centuria. Y es así por las innovaciones y los cambios solo pueden producirse dentro de una tradición. Y en tal sentido, es oportuno recordar que según García Jurado $(2008 b, 184)$ «los fundamentos de una Historiografía Literaria ligada a una incipiente conciencia de la Tradición Clásica» hay que buscarlos en la Vida de Virgilio de Mayáns (1777-1778)9.

En la fecha de publicación de la Vida de Virgilio, Mayáns ya había abandonado la Real Biblioteca, pero había sido nombrado Alcalde Honorario de la Real Casa y Corte. Por otra parte, y según García Jurado (2008b, 185), la obra de Mayáns «está concebida en el marco de un ambicioso proyecto de edición de las mejores traducciones de Virgilio al castellano y con el claro propósito de fomentar el buen gusto literario nacional mediante la imitación de los mejores modelos por parte de la juventud». Sostengo que este propósito tiene como contexto el reconocimiento del atraso cultural y científico de España y el deseo de superarlo, y ambas cuestiones debieron tener también su "anclaje" institucional. Por lo demás, y como se recordará, el trabajo de Mayáns es contemporáneo de la obra de otro bibliotecario real, el Ensayo de una biblioteca de traductores españoles de Pellicer (1778), que es un hito de la historiografía de la literatura española en el siglo XVIII. Al decir de García Jurado (2008b, 185), Pellicer es el precursor de la Bibliografia Hispano-Latina clásica de Menéndez y Pelayo.

En tal sentido, pueden verse Perdomo-Batista 2013, 2016 y 2020. Y en el ámbito específico de la tradición latina Perdomo-Batista 2011.

9 Creo, no obstante, que otro hito muy importante es el tomo VII de la Historia literaria de los hermanos Rodríguez Mohedano (1781), al que ya nos hemos referido. Las polémicas suscitadas por las críticas de Bettinelli y Tiraboschi y las respuestas a que dieron lugar por parte de los españoles son un hecho muy importante en relación con los orígenes de la Historiografía de la Literatura en el siglo XVIII. 
Puede decirse que en sus orígenes la Historiografía de la Literatura Latina ha tenido un carácter ancilar respecto de otras disciplinas, como señala García Jurado (2008b, 184). Pero si esto es cierto, no lo es menos que su contribución a la Historiografía moderna de la Literatura Española ha sido importante. Y siendo cierto esto, no parece aventurado afirmar que no ha sido ajena a la conformación de la escuela de filología española. Y en esa dirección va nuestro análisis. En este sentido, el legado ilustrado será retomado cuando sus herederos ideológicos, los liberales, accedan al poder. Para realizar nuestro análisis, examinaremos alguna de las ideas expuestas por Canalejas en relación con las de Menéndez Pidal, analizadas y contextualizadas por José Portolés (1986) en un trabajo ya clásico. Contamos también con el estudio de Hans Helmut Christmann (1985). El desarrollo de las ideas lingüísticas de los paradigmas comparatista, neogramático, positivista e idealista en relación con el desarrollo histórico de la lingüística románica ha sido oportunamente examinado por Dan Munteanu (2017) no hace mucho. Y a propósito del propio Menéndez Pidal, Carlos Garatea (2005, 21-22) ha señalado que, aunque algunas ideas del maestro (por ejemplo, el individuo como principal agente del cambio lingüístico) podrían llevarnos a identificarlo con el idealismo, esta sería una conclusión muy apresurada, porque don Ramón «supo conjugar distintas perspectivas de trabajo conforme fue avanzando en sus investigaciones». Y así lo exponemos ahora, porque conviene no olvidarlo cuando valoremos la posición de Canalejas en el contexto intelectual de la época.

\section{Materiales y metodología}

Los Apuntes para un curso de literatura latina de Canalejas tienen como precedente la asistencia de este a las clases de la cátedra de Alfredo Adolfo Camús en la Universidad Central de Madrid, a la que concurrieron también Menéndez y Pelayo, Pérez Galdós ${ }^{10}$ y Clarín. Según García Jurado (2008a, 168), Camús impartía la asignatura de Historia de la Literatura Griega y Latina, que se dividía en dos cursos, el primero dedicado a la Literatura Latina, y al que acudían tanto los alumnos de Filosofía y Letras como los de Derecho, y el segundo a la Literatura Griega, al que solo asistían los alumnos de Letras. Conservamos una copia manuscrita de los apuntes tomados por Canalejas en el curso 1869-1870. El idiógrafo se conserva en a la biblioteca de filología de la UCM (BH FLL 49834), y es obra de un tal Francisco Mayone del Mazo (1871), que afirma al principio del texto que es copia de los apuntes de Canalejas. Tenemos, además, algunos impresos relacionados con los Apuntes de Canalejas a los que nos referiremos a continuación y de los que no vamos a ocuparnos aquí, pero que permitirían un examen más contextualizado y pormenorizado de los propios Apuntes y aún de la Historiografía de la Literatura Latina a finales del siglo XIX.

En primer lugar, debe señalarse el Programa de un curso de Principios Generales de Literatura explicado en la Universidad Central (1872-1873), publicado en Madrid en 1873. Obra también de Canalejas, sin duda son el resultado del trabajo como auxiliar en la cátedra de Literatura Española de su tío Francisco de Paula.

Tenemos noticia además del programa de algunas asignaturas impartidas por Francisco de Paula Canalejas y otros materiales suyos (relacionados en Valle López 1990).

10 Los Apuntes de Galdós se conservan en al Casa-Museo Pérez Galdós de Las Palmas de Gran Canaria, y sobre ellos estamos preparando otro trabajo. 
Finalmente, es preciso mencionar el Programa de Literatura Griega y Latina redactado por el propio Camús ${ }^{11}$.

Respecto de la metodología, es posible efectuar un análisis de los Apuntes a partir de diferentes perspectivas. En primer lugar, pueden tenerse en cuenta las distintas tendencias de la historiografía literaria de la época. Tales tendencias son la historiografía del siglo XVIII, la historia comparada, el positivismo y el idealismo. En general, estas tendencias son foráneas, a diferencia de las tradiciones propias, que suelen tener un "anclaje" institucional, como ya hemos comentado a propósito de la filología española del siglo XVIII. No obstante, y como también se ha señalado, aunque la explicación de los hechos a partir de corrientes y tendencias dominantes puede ser muy útil por su valor heurístico, resulta insuficiente. Por ello, son precisas otras perspectivas de análisis como, por ejemplo, y, en segundo lugar, el examen de los tópicos y argumentos de las propias obras historiográficas. Y esta segunda perspectiva de análisis puede desarrollarse en dos direcciones.

Por un lado, pueden examinarse los aspectos epistemológicos y metodológicos, y esto último incluye también los aspectos materiales de las obras. Me refiero a si las obras contienen referencias metodológicas y cuáles son estas, a cuáles son los criterios de periodización y secuenciación empleados (géneros o cronología y como se establece esta -por ejemplo, por reinados-), al número y la extensión de las etapas y períodos abarcados, a si se incorporan o no los primeros monumentos literarios y, en definitiva, a cómo se organiza la asignatura. Y desde el punto de vista material, es preciso considerar si nos hallamos ante unos apuntes (¿manuscritos o impresos? -y en este caso, ¿se trata de una editorial especializada con una tradición previa?-), una antología, un manual o un programa de curso, además de las características textuales y discursivas (existencia y naturaleza de los paratextos, inserción de ejemplos, extensión y proporción de cada apartado, notas al pie, referencias bibliográficas, etc.). Debemos tener en cuenta que los programas de la asignatura no son ajenos a la coyuntura institucional, en nuestro caso, la difusión del krausismo, el surgimiento de la Institución Libre de Enseñanza, además de la consolidación de un estado liberal. Y en esta línea, es oportuno comprobar si hay valoraciones administrativas (por ejemplo, las censuras previas y los permisos de impresión).

Por otro lado, podemos examinar estrictamente los contenidos; bien atendiendo a los autores tratados y específicamente a la presencia de ciertos autores y a las valoraciones que de ellos se hacen: Plauto, Terencio, Cicerón, César, Lucrecio, Virgilio, Séneca y Lucano entre otros; bien atendiendo a los argumentos: la valoración de ciceronianismo, el cotejo de la literatura griega y la romana, las referencias a la lengua latina, el tratamiento de la Literatura Latina medieval y renacentista, etc. Finalmente, una cuestión del máximo interés sería examinar cómo la historiografía de la literatura latina ha condicionado el canon de los autores modernos (por ejemplo, y sin ir más lejos, en el caso del propio Galdós a propósito de Plauto y Terencio, como ha señalado García Jurado [2008a, 173 y García Jurado 2004]). Y desde el punto de vista

\footnotetext{
García Jurado (2008a, 169) señala que fue publicado primero en latín en 1848 y 1850, y después en castellano en 1861 y 1876. Hemos podido ver una edición española de 1864 (Madrid, imprenta de las Escuelas Pías). Existen, además, otros trabajos de Camús interesantes, como los Preceptistas latinos para el uso de las clases de Principios de Retórica y Poética (1846), el Curso elemental de retórica y poética (1847) y el Compendio de Historia Universal (1842), que contiene una interesante introducción sobre el modo de escribir la historia, lo que quizá permitiría establecer interesantes vínculos entre la tradición clásica y la conformación de la Historiografía española a finales del siglo XIX.
} 
del Análisis Crítico del Discurso se puede valorar la contribución de los materiales a la creación de una imagen o una memoria individual o colectiva y a los estereotipos culturales. Y es interesante advertir también la presencia de adoctrinamiento y el grado y la dirección de este.

Todo ello contribuye a crear un «código disciplinar» (R. Valls, 1997-1998, 121) que en el caso de la Historiografía de la Literatura Latina tiene su origen a principios del siglo XIX y se consolida a mitad de la centuria. Se trata de ir desvelando ese código disciplinar que naturalmente tiene su historia. Y ese análisis crítico de la disciplina me parece que debe ser uno de los principales objetivos del enfoque historiográfico en la actualidad (E. F. K. Koerner, 2007 y Swiggers 2009).

Para nuestro análisis de los Apuntes de Canalejas, debemos tener en cuenta que el contexto fue especialmente complejo a finales del siglo XIX, porque en relación con la Historiografía de la Literatura, se entremezclaron las ideas de la lingüística histórico-comparada, que vino a ser contestada después por los neogramáticos, y ambas tendencias fueron luego matizadas por el pensamiento idealista cuyas raíces, sin embargo, eran anteriores (Humboldt) ${ }^{12}$, y a todo ello hay que unir el pensamiento krausista, el regeneracionismo y las inquietudes de la Generación del 98, y, en el ámbito institucional, la creación de la Institución Libre de Enseñanza. Por tanto, si siempre resulta arriesgado identificar en la obra de un autor las huellas del pensamiento y las corrientes de su época, en este caso lo es aun más. Para aminorar estos riesgos, será preciso recordar el contexto cronológico preciso de la obra, que comprende dos hechos: la experiencias previa inmediata, esto es, la adjuntía en la cátedra de su tío Francisco de Paula y la publicación de los Principios de literatura española, 18721873; y la publicación de los dos tomos de los Apuntes, es decir, 1874-1876, aunque naturalmente, debemos ser conscientes de que la ideas ya están en el aire y forman parte del momento antes de su cristalización en los textos. Por lo mismo, y en pos del mayor rigor posible, nuestro análisis empezará por los aspectos factuales (rasgos materiales y discursivos de la obra y los contenidos de esta) para pasar finalmente a las interpretaciones sobre las influencias visibles en la obra y a las valoraciones sobre el significado de esta en su contexto.

\section{Discusión y resultados}

Desde el punto de vista material (y paratextual ${ }^{13}$ y discursivo), lo primero que llama la atención es la primera palabra del título «Apuntes». No se trata, por tanto, de un «programa», de modo que su condicionamiento institucional parece menor. Pero la propia voz «apuntes» tiene también otras implicaciones. Ciertamente no tenía en 1874 el significado didáctico que le damos hoy a la palabra en plural, sino que en singular significaba 'apuntamiento', como se puede comprobar en el Diccionario académico de $1869^{14}$. La palabra remite a la idea de unas notas no definitivas y, por tanto, a un propósito no dogmático que desde el punto de vista historiográfico nos

Sobre la cuestión puede verse Javier Espino (2020).

13 Para el concepto de paratexto, y además del trabjo clásico de Genette (1989), puede verse el de Maite Alvarado (2009).

14 Puede consultarse a través de la aplicación en línea del Nuevo tesoro Lexicográfico de la lengua Española de la RAE: http://ntlle.rae.es/ntlle/SrvltGUIMenuNtlle?cmd=Lema\&sec=1.1.0.0.0. 
distancia de una actitud positivista. Bajo el título aparece un gracioso grabado de Luperca con los dos niños. Seguramente es una idea del editor, pero contaría con la aprobación del autor. Es interesante porque nos remite al mundo del mito, en un gesto que me parece más próximo de lo imaginativo y lo estético que del historicismo positivista. Y naturalmente, no se trata de unos meros «apuntamientos», sino de una extensa obra de 423 páginas dividida en dos volúmenes el segundo de los cuales lleva el subtítulo de «Siglo de Oro». El concepto de «siglo de oro» surge en el siglo XVIII, y remite a una concepción historiográfica que entiende la historia como la alternancia de etapas de esplendor y decadencia, idea de filiación romántica que bebe en el mito de las edades y que atraviesa toda la Literatura Latina, aunque sus fuentes sean anteriores ${ }^{15}$. El segundo tomo es más extenso que el primero (240 páginas frente a 180), y si tenemos en cuenta que este incluye la introducción propiamente dicha y unos capítulos introductorios, se nos antoja que la distribución implica también cierta apreciación sobre las dos etapas. Ambos tomos incluyen al final unos índices bien detallados en forma de sumario.

El primer tomo lleva una introducción además de un par de capítulos (caps. I y II) de carácter también introductorios. Este tomo se ocupa de los primeros monumentos de la Literatura Latina y llega hasta los prosistas anteriores al Siglo de Oro: de los cantos arvales a los Gracos y Craso. El segundo tomo comienza con un Capítulo Preliminar de veintiocho páginas. Este capítulo dedica algunas líneas a la épica romana y termina con la prosa del siglo de oro. El capítulo primero del tomo II está dedicado enteramente a Catulo; el último, a Cicerón. Cicerón es precisamente el autor al que más páginas se le dedican; 34 frente a las 12 de César, las 31 de Ovidio, las 30 de Virgilio, las 21 de Horacio o las 13 de Catulo. Sin embargo de que el segundo tomo es más denso y se demora más en los autores, ambos tienen el mismo número de capítulos: 13. Se excluye la literatura medieval y renacentista, adoptando un planteamiento que me parece más moderno porque la Literatura Latina se vincula y supedita no a la historia de la lengua latina, sino a la historia de «la civilización romana» (como puede suponerse ha perdido peso lo lingüístico frente a lo literario). Por eso afirma el autor, en clave idealista humboldtiana, «Cada lengua tiene, como a la civilización a la cual sirve, caractéres propios y cualidades privativas» (Canalejas, 1874-1876, t. I, p. 6).

Así pues, en la secuenciación parecen conjugarse criterios cronológicos con criterios genéricos y aun otros de carácter valorativo (estéticos). No obstante, la periodización no esta basada en criterios solo de género, como podía ser común en la poética y la retórica del s. XVIII. Influida por el historicismo, pareciera como si la propia disciplina intentara su propio deslinde sin disponer aún de unos criterios historiográficos claros.

La introducción del tomo I ocupa 8 páginas y gira en torno a dos ejes temáticos en los que se van hilvanando las ideas: en primer lugar, la utilidad de los estudios clásicos y de la historia literaria; en segundo lugar, el desarrollo de la «ciencia filológica».

Respecto de lo primero, Canalejas empieza en clave regeneracionista afirmando la utilidad e los estudios clásicos apelando al patriotismo, pues sin ellos España quedaría relegada de los avances del conocimiento que se producen en toda Europa en este ámbito. Naturalmente, la idea y la actitud enlaza con la polémica sobre la ciencia española y con el deseo de recuperación nacional que se da en la centuria anterior,

Para el concepto de Siglo de Oro aplicado a las lenguas clásicas puede verse García Jurado (2007). 
cuestiones a las que ya nos hemos referido. En este contexto, Canalejas desprecia los prejuicios de «romancistas» y «ciegos fanáticos». Representaban los primeros a los medievalistas. Como se sabe, la historia comparada favoreció los estudios medievalistas, aunque este ámbito de investigación filológica se había desarrollado ya, y con gran esplendor, desde la centuria anterior. Con la segunda expresión denominativa se refería Canalejas a los neocatólicos. Censura los reticentes prejuicios de unos y otros contra el estudio del mundo clásico. Este posicionamiento es una huella de la contraposición ideológica que se está produciendo entre una corriente liberal reformista (representada por el propio Canalejas) y otra católica (neocatólicos y romancistas). Con su posición, Canalejas supera la herencia del historicismo comparatista $\mathrm{y}$ el romanticismo ${ }^{16}$, y trasciende esa oposición ideológica en beneficio de un interés específico: la Historiografía de la Literatura Latina. Y añade después, en ese contexto utilitario y regeneracionista al que nos hemos referido, que el estudio del clasicismo grecorromano puede contribuir al «genio nacional». La idea no es nueva, y podemos hallarla también en la centuria anterior, en la que se consideraba que el estudio de los clásicos latinos e hispanos era la vía para la recuperación nacional. Me parece que hay que interpretar la idea, por tanto, en clave ilustrada, lo que resulta patente, por ejemplo, en el pensamiento y la obra de Mayáns.

Canalejas (1874-1876, t. I, p. IV) afirma que la literatura es la expresión del genio de los pueblos, según una concepción de filiación romántica próxima también a la historia literaria comparada. Y señala «el tinte jurídico de la Literatura latina», que avala con citas textuales de Plauto, Ovidio, Propercio, Cicerón, Lucilio y Tácito. Por tanto, el estudio de la latinidad resultaba muy provechoso para el estudio del derecho. Esta idea la hallamos también en la centuria anterior, y en ella es posible identificar una línea de trabajo filológica específica: la de los historiadores del derecho, que se puede rastrear en la obra de Mayáns e incluso en la del P. Flórez, aunque se remonta a los trabajos de Antonio Agustín en siglo XVI (Perdomo-Batista 2020).

En torno al segundo eje temático que habíamos señalado, concerniente al desarrollo de la «ciencia filológica», Canalejas pondera los adelantos en la clasificación de las lenguas. Señala los trabajos del P. Hervás en la centuria ilustrada, y en el ámbito de la filología y la gramática comparadas, los de Schlegel y Bopp. Naturalmente, no faltan las alusiones al sánscrito. Y relaciona los principales filólogos y gramáticos de la época: Bopp, Grimm, Curtius, Dietz, Max Muller, Ascoli, Breal, etc.; lo que desde luego me parece un testimonio de su voluntad de actualización científica. El interés de Canalejas es situar al latín adecuadamente dentro del catálogo de las lenguas del mundo y relacionarlo adecuadamente con las lenguas antiguas y las románicas, además de establecer su origen. Lo que se advierte de manera inmediata es que lo lingüístico sigue siendo importante para la historia literaria, y supongo que lo que buscaba Canalejas era unos fundamentos filológicos (lingüísticos) sólidos sobre los que orientar su actividad historiográfica. La historia de la lengua es entonces un instrumento de la historia literaria, como preconizaba la metodología histórico-comparada. Pues en efecto a comienzos del siglo XIX, como señala Munteanu $(2017,62)$ el pensamiento lingüístico y el literario están unidos, y la lingüística histórica y la historia literaria (en el sentido actual) surgen aproximadamente en la misma etapa (especialmente en el ámbito de la filología románica). El propio Canalejas (1874-1786,

${ }_{16}$ Para los conceptos de romancista y neocatólico puede verse R. Valls (1997-1998), y para lo relativo a las corrientes idealistas, puede verse José Portolés (1986) además de Munteanu (2017). 
t. I, p. III) así lo reconoce cuando afirma «Los estudios literarios, siguiendo el rumbo que les trazaban los filólogos y aprovechándose de sus conquistas y descubrimientos, aceptaron en las primeras décadas de este siglo es sistema de comparación». Y añadía después que, en el campo de la Literatura Latina, los ámbitos privilegiados de la comparación, por razones obvias, eran la literatura helena y la hispana.

Finalmente, Canalejas también hace en la Introducción algunas apreciaciones sobre el propósito de la obra. Conforme a su título, según hemos visto, señala que nos se trata de un libro fundamental, sino más bien, de una actualización científica y didáctica de la Historiografía de la Literatura Latina. Canalejas reconoce la obra y el magisterio de Alfredo Adolfo Camus, y pondera el interés del estudio biográfico para la historiografía literaria. Y añade (mantengo siempre la ortografía original):

Concédese á las biografías generalmente escasa importancia, juzgando con crítica vulgar, que no ofrecen provecho ni utilidad alguna, pero nosotros pararémos en ellas la atención advirtiendo que en toda obra literaria, aún en las producciones épicas por esencia impersonales, imprime sello característico la individualidad del escritor (Canalejas, 1874-1876, t. I, vIII).

Este reconocimiento del individuo contrasta vivamente con el contexto del historicismo positivista en el que se formó el autor. En la consideración de la lengua como expresión individual nos aproximamos al pensamiento idealista. Aunque quizá arriesgue demasiado, me aventuraré a señalar que advierto en Canalejas positivismo metodológico, pero no epistemológico ${ }^{17}$.

Me parece que también tiene un carácter introductorio el capítulo I del primer tomo, cuyas líneas temáticas son estas: la naturaleza de la historiografía, y las etapas de la Literatura Latina. Respecto de lo primero, desecha la concepción meramente cronológica o «evenemencial», y defiende un historiografía crítica, en la línea de Mommsem o Niebuhr, que quede a salvo de un historicismo positivista subyugado por el dato. En tal contexto, Canalejas nos previene contra «las fábulas que encubren el origen y primeros alientos de Roma», y enseguida censura los excesos de Mommsem y Niebuhr. Creo que podría decirse que se halla superada la concepción de una historiografía de carácter literario.

Respecto a la filogénesis y evolución del latín, lo primero que rechaza es el viejo prejuicio heleno según el cual todas las demás lenguas eran bárbaras. Advierto en ello la superación de cualquier tipo de fetichismo residual por el Mundo Clásico. La idea es rechazada en virtud de «la tendencia que se observa en todos los pueblos ante-cristianos á no reconocer los lazos específicos que les ligan a la humanidad entera» (Canalejas, 1874-1878, t. I, p.3). La afirmación es una herencia del viejo cosmopolitismo ilustrado, bien presente en un político liberal, como cabría esperar. Niega la ascendencia del sánscrito sobre el latín y el griego y apela a Max Müller para situar al latín dentro de las ramas indoeuropeas: «teutónicas, itálica, helénica, céltica, eslava, índica e irania» (Canalejas, 1874-1878, t. I, p. 5). Creo que no se puede negar

Utilizamos ambas expresiones en el sentido que les da Carlos Garatea (2005, 20, n. 41), que parte de las ideas de Karl Vossler citadas por Iorgu Iordan, aunque aquel habla de "positivismo metafísico», que considera los hechos de la lengua «solo como resultados de fuerzas internas de la lengua». El «positivismo metodológico» plantea «la exigencia de contar con la mayor cantidad posible de material que apoye toda interpretación posterior». 
su voluntad de rigor y actualización científicos. Y en este mismo contexto también son interesantes sus observaciones sobre las relaciones del latín y de los dilectos de Italia y sus provincias con las lenguas neolatinas. Naturalmente, la cuestión remite a la polémica sobre el latín vulgar y el origen de las lenguas románicas (Munteanu, $2017,85)$. Respecto del alfabeto y la ortografía latina, señala que lo más prudente es adoptar la ortografía de los gramáticos de la última época, porque esta corresponde a la pronunciación o al uso establecido. Y luego manifiesta la dificultad de determinar la verdadera pronunciación del latín, actitud positivista que lo aproxima al pensamiento de los neogramáticos.

Finalmente, y en relación con las etapas de la Literatura Latina, distingue estas 5: «infancia» (desde la fundación de Roma hasta el fin de la primera guerra púnica en el año 512), «adolescencia» (hasta la muerte de Sila en el año 676), «edad viril o Siglo de Oro» (hasta la muerte de Augusto en el 767 de Roma), vejez (hasta la muerte de Trajano en el 870), «Decrepitud» (hasta la ruina del imperio en 1229). Pero no advierto en ello ningún influjo del darwinismo, sino más bien una mezcla del mito de las edades y el pensamiento de Humboldt.

Resulta interesante también el Capítulo preliminar que introduce el segundo tomo, que se desarrolla en tono a dos ejes temáticos: la naturaleza de la crítica y las causas del esplendor de la Literatura Latina durante el Siglo de Oro.

La indagación sobre la naturaleza de la crítica, herramienta fundamental para la historia literaria, obliga a Canalejas a preguntarse por la naturaleza de arte y, consecuentemente, de lo literario. En línea con el pensamiento idealista, el autor reivindica la libertad creativa individual, lo que reclama una crítica libre de prejuicios, modas y códigos estéticos (adviértase la reivindicación final de la individualidad):

[...] sin belleza no hay ideal y sin ideal no hay arte, el génio extraviado escucha el reflexivo llamamiento [...] de la Crítica, que le induce a corregir sus extravíos [...] no porque constituyan delito penado en los códigos de los preceptistas, sino porque desacatan la ley fundamental que se desprende lógicamente de la esencia misma de la inspiración artística. Fuera de esto, no caben límites para el Arte que no repugnen al espíritu moderno: toda idea, toda convicción, todo sentimiento pueden servir de asunto a los cantos del poeta, aunque pequen gravemente contra los principios que imperan en la sociedad: el artista encarna sus creaciones y expresa sus conceptos como de suyo se informan en su espíritu [...] (Canalejas, 1874-1876, t. II, p. v-VI)

Pero su actitud se aproxima al positivismo metodológico cuando en seguida afirma «La Crítica literaria [...] lejos de alimentarse con vanas abstracciones, ha aprendido á considerar la realidad de los hechos».

Y en esta indagación sobre la naturaleza de la crítica y del arte, Canalejas necesariamente tenía que preguntarse por el hecho literario. Esta es su respuesta: «[...] la Literatura es la expresión de la esencialidad espiritual humana que se significa en cada pueblo según las condiciones propias del genio y el carácter nacional, diversificadas á su vez en el transcurso de la historia» (Canalejas, 1874-1876, t. II, p. v-VI). Hallamos, pues, tradición («esencialidad») y evolución («diversificadas á su vez en el transcurso de la historia»). Creo que se advierte cierto influjo idealista, y que, al menos en su primera etapa, ni el mismo Pidal hubiera rechazado de plano estas afirmaciones, que, según Portolés $(1986,41)$, podríamos relacionar con el pensamien- 
to krausopositivista, superación (como síntesis armónica) del idealismo krausista original por el positivismo científico. Estas ideas remiten también a la creencia en la existencia de un «carácter nacional» (condicionado sobre todo por el clima) ${ }^{18}$, cuestión que había generado polémica en la centuria anterior y que luego contribuirá, a partir de las críticas irresponsables de los ilustrados franceses, a conformar la leyenda negra ${ }^{19}$.

Y a propósito de los autores del Siglo de Oro añade después: «reconociendo en las obras de les escritores que concretamente examinaremos después la manifestación ideal y culta, pero libre y espontánea, del genio de su pueblo en aquella faz que revela durante el período histórico en que consigue el apogeo de su grandeza política y literaria» (Canalejas, 1874-1876, t. II, p.VII). Me parece difícil negar la presencia de un pensamiento idealista muy evolucionado, porque advierto, junto a la idea de la literatura como expresión individual, la idea de que lengua y literatura evolucionan, y lo hacen colectivamente.

En cuanto a la segunda línea temática, a la explicación del esplendor alcanzado por la Literatura Latina durante el Siglo de Oro, Canalejas no lo atribuye a la forma de gobierno (la acción del príncipe), porque esto le parece más consecuencia que causa, sino a las «leyes y principios», a «las costumbres y prácticas sociales». Con muy aguda conciencia histórica, atribuye el florecimiento literario al carácter crítico de la nueva época en la que caen los «antiguos ideales» y devienen «nuevos principios y creencias». Así pues, la causa del florecimiento del Siglo de Oro fue la libertad, porque los cambios políticos y religiosos, el escepticismo y la apatía que genera el cansancio producido por las mudanzas, «determinan una tolerancia que permite al escritor espaciarse sin temores ni sobresaltos [...] porque, entónces es como nunca activa la vida espiritual». La íntima relación entre libertad y esplendor literario y cultural también había sido expuesta en la centuria ilustrada, y no es extraña su pervivencia en un liberal. Pues en efecto, reformistas e ilustrados atribuyeron en parte el atraso de la nación a la falta de libertades en el ámbito intelectual.

Finalmente, y respecto a las relaciones entre la literatura griega y la latina, Canalejas reconoce la deuda de esta con aquella, pero añade: «No se entienda por ello que estas imitaciones son frecuentemente copias serviles» (Canalejas, 1874-1876, т. II, P. XV)». Canalejas reconoce que aún no está claro el influjo de la Literatura Latina en el «genio patrio», porque la cuestión se ha visto empañada por la pugna entre «clásicos y románticos, pero considera que esa influencia ha existido y «ha producido provechos inapreciables». Interesa esta referencia porque va dando cuenta de la comunidad de orígenes de la Historiografía de la Literatura Latina y la Española.

Antes de pasar a las conclusiones, aún debemos dedicar algunas líneas al análisis que hace de algunos autores latinos especialmente significativos para la Historiografía de la Literatura Latina, como hemos señalado en la metodología: Plauto, Terencio, Lucrecio, César, Cicerón, Virgilio.

\footnotetext{
18 No en vano, Canalejas atribuye a los autores hispanos y a los hispano-latinos (Lucano, Séneca, Floro, Quintiliano) ciertos rasgos propios de las «latitudes meridionales (Canalejas, 1874-1876, t. I, p. V-VII)».

19 En efecto, Montesquieu, por ejemplo, había afirmado en las Cartas persas (1721) que el clima había fomentado la ociosidad de los españoles. Y en El espíritu de las leyes (1748) sostuvo que las diferencias entre los pueblos se debían a la influencia del clima. En España las tesis ambientalistas fueron sostenidas por el jesuita español Juan Francisco Masdeu, aunque muy matizadamente. Masdeu fue autor de una importante Storia critica di Spagna e della cultura spagnuola (1781) que en absoluto es ajena a las polémicas suscitadas por las críticas de Tiraboschi y Bettinelli a propósito de los autores hispanos en la Antigüedad y en el siglo XVII.
} 
Canalejas dedica a Plauto los capítulos IV, v y vi del tomo primero. Analiza el estilo, examina tipos y caracteres, se detiene en las obras y discute algunas atribuciones. Señala su papel como fundador de la comedia romana y su importante influjo en la conformación del teatro moderno (es interesante su alusión a Molière); y destaca (Canalejas, 1874-1876, t. I, 64-65) «el interés de la obra plautina para la estudio de la sociedad romana de su tiempo en los accidentes de la vida privada», y destaca «las enseñanzas históricas, morales y jurídicas que se desprenden de un estudio atento del teatro de Plauto», en lo que me parece otra muestra del influjo del historicismo idealista, y me sugiere que el autor estudia la literatura como parte de un proyecto historiográfico más amplio que se interesa por el estudio de una civilización. Se trata, creo, de una tendencia que no está distante de las ideas de la Institución Libre de Enseñanza ni del pensamiento de Pidal. Y en cuanto a los reparos morales que pudieran hacerse a la obra plautina, señala (p. 66) que «el pensamiento moral domina siempre en la mente de Plauto [...] hace que humildes siervos den en el Teatro públicas lecciones de justicia a los senadores y a los grandes». Y apela a Shakespeare, Lope y Cervantes para exonerarlo ante quienes denuncian los excesos verbales (por deshonestos) de su obra. De modo que, si la crítica de Canalejas no logra apartarse completamente del ámbito de lo moral, al menos trata de superar los prejuicios a través de una mirada menos limitada.

A Terencio se dedican los capítulos VIII, VIII y parte del Ix. Repasa la biografía, relaciona obras, analiza las comedias y personajes y establece vínculos con la obra de Plauto. Y como hiciera con este, y acaso por la misma razón, destaca el valor moral de la obra de Terencio y pondera sus «principios filosóficos». Y destaca como una de las principales preocupaciones de Terencio la de la educación, «admirablemente planteado en los Adelphi» (p. 126). Naturalmente, la preocupación por la educación, de raigambre ilustrada, no ha de ser ajena al pensamiento liberal, al regeneracionismo y al krausismo.

A Lucrecio se dedica el capítulo XII del tomo I. Se ocupa de los escasos datos biográficos, de las consecuencias de las opiniones religiosas de Lucrecio, de su relación con Epicuro, y, fundamentalmente, De rerum natura y sus principales temas. Libre de prejuicios y de condicionamientos morales y religiosos, manifiesta abiertamente su admiración por Lucrecio. Y, coherentemente, lo que le parece más admirable es precisamente la construcción de un sistema racional: «en el admirable poema de rerum Natura campea donosamente la razón humana, tegiendo la urdimbre de un sistema apto para ornarse y pulirse con los atavíos del arte por su levantada idealidad» (p. 160). Advierto en esta surte de elogio a una razón soberana la huella de la mentalidad ilustrada, allegada quizá a través de la mentalidad liberal. Canalejas dedica unas líneas del final del capítulo a las ideas de Lucrecio (canto v) a propósito del problema del origen del lenguaje. Según Canalejas (1874-1876, t. I, p. 168), en Lucrecio el lenguaje es consustancial a la naturaleza humana.

A Cicerón dedica el capítulo XIII, último del tomo II. Se ocupa de los aspectos biográficos (familiares, literarios y políticos) del autor, de las obras retóricas, de las obras políticas y, al final del capítulo, del epistolario ciceroniano. Como sería muy prolijo demorarnos en todos los aspectos en los que se extiende, solo me detendré, porque me parece muy importante desde el punto de vista historiográfico, en la cuestión del ciceronianismo ${ }^{20}$. En la conocida polémica del Renacimiento, Canalejas ( $p$.

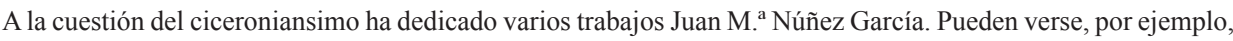
Núñez García 1991 y 1996. 
199) se alinea con Erasmo de Rotterdam, que en su Ciceronianus (1528) se había opuesto a la adoración fetichista y acrítica del estilo ciceroniano, aunque no se ponen en duda los altos méritos de la obra del arpinate. Canalejas (p. 199) se identifica con Erasmo en lo que me parece una censura de toda postura dogmática y acrítica. Se trata de una actitud próxima a la órbita de los intelectuales liberales.

A César se dedican el capítulo VII y un fragmento del VIII. Se ocupa de la formación de César y de su biografía personal y política, de sus campañas y de las circunstancias de su muerte. Analiza el estilo y presenta las obras, incluido su epistolario. Concluye con un apartado dedicado a César como orador. Nos interesa, sobre todo, el posicionamiento ideológico de Canalejas a partir de su examen de la biografía y la obra de César. Lo primero que hace (p. 125) es prevenirnos contra la «pasión política», que «envenena la ciencia y falsea la historia». Hay pues, una actitud precavida que revela una conciencia historiográfica aguda. Resultan muy interesantes, porque manifiestan su posición historiográfica y aun intelectual, sus valoraciones, que transcribimos a continuación.

[...] procuraremos descartarnos de ese individualismo idealista, en nombre del cual se le inscribe en el catálogo de los grandes perturbadores de la sociedad antigua [y aquí cita en nota al pie a Ramée, 1870], evitando igualmente la avasalladora influencia de un cierto providencialismo filosófico, puesto hoy en moda, atentando a los fueros de la libertad y la conciencia humana, acogido con entusiasmo y observado con escrúpulo sumo por los que hallan en él la legitimación de poderes arbitrarios y aun despóticos [y cita aquí en nota al pie a Napoleón III, 1865].

Independientemente de la advertencia final contra los excesos y la tiranía, la cita me parece extraordinaria porque puede notarse como Canalejas trata de formular un modelo historiográfico personal armonizando la acción creadora del individuo («individualismo idealista») con las ciegas fuerzas de la historia y la sociedad («providencialismo filosófico»). Ninguno de los dos extremos parece satisfacerlo. En su relato, Canalejas tratará de aunar ambos tipos de explicaciones y creo que con ello se adelanta a su momento, porque piensa en una individualidad que es, al mismo tiempo, histórica. Resulta inevitable pensar en algunos colaboradores de Menéndez Pidal en el Centro de Estudios Históricos, como Américo Castro (Portolés, 1986, p.88). Porque la cita de Canalejas parece ir en la dirección de una temprana superación del historicismo positivista.

A Virgilio se dedica el cap. v, que se ocupa de los datos biográficos, su educación literaria, su carácter y costumbres, sus comentadores y traductores, y sus obras: Églogas, Geórgicas, la Eneida y los poemas menores. Nos interesan sobre todo, por su valor historiográfico las consideraciones sobre el carácter nacional de la Eneida. Vemos lo que dice.

Virgilio, concertando la tradición poética con la tradición histórica, pidiendo á aquella modelos y a ésta asunto de inspiración, escribe su Eneida, poema erudito, en el cual no campean como en la Ilíada el espontáneo entusiasmo, y el vivo patriotismo de un pueblo apasionado y viril, sino que se revela la brillantísima imitación de tipo artístico importada de Grecia, esfuerzo incomparable que conforma el carácter colectivo y la condición esencialmente objetiva del arte épico. (Canalejas, 1874-1876, t. II, p. 83). 
Así pues, Canalejas reconoce las excelencias de la obra del mantuano, pero considera que no es la expresión del carácter de un pueblo (y de lo popular), como sucede con al Ilíada. Ya en el Capítulo preliminar había expuesto:

Menos espontánea que las Geórgicas es sin duda alguna la Eneida, poema erudito en el cual no campean como en al Ilíada las creencias, los sentimientos y las aspiraciones de una civilización primitiva y viril, sino que se revela el intento de un poeta genial $[\ldots]$ esfuerzo generoso cuya esterilidad confirma el carácter colectivo y la ley esencialmente objetiva del arte épico [...] privan a los cantos de Virgilio de la frescura y lozanía que caracterizan a los poetas espontáneos [...] La índole didáctica y el carácter erudito de estas manifestaciones de la Epica romana los priva de aquella intimidad y consorcio con el genio del pueblo y la costumbres de la época que tanto aprovechan en el arte Epico espontáneo para el estudio de la sociedad cuyas glorias canta y cuyas tradiciones celebra. (Canalejas, 1874-1876, t. II, p. 83-84).

Aquí resulta inevitable evocar la figura de Menéndez Pidal. No se advierte, naturalmente, aquella fusión entre tradición y evolución que caracteriza el pensamiento de Pidal. Porque la epopeya como expresión del espíritu de pueblo ya era una interpretación romántica (Portolés, 1986, 29). Además, el elemento «popular» no se ha transformado aún en la «tradición», como en el pensamiento y la obra de Pidal, pero sí hay una alusión a aquella, lo que parece indicar que se va en esa dirección.

La visión de la historia literaria como la historia de una civilización se advierte bien en la siguiente cita, que revela, a mi entender, el influjo del historicismo idealista:

[...] ni la Geórgicas, ni mucho menso las Metamorfosis, ni aun la misma Eneida, nos instruyen del movimiento de las ideas ni del desarrollo y las mudanzas de las instituciones políticas y sociales o de las costumbres y hábitos privados del pueblo Romano.

Más provechosa para este estudio, más nacional si así vale decirlo, es en Roma la poesía Lírica (...) [porque] en todo el período clásico Greco-romano, la Poesía lírica se relaciona íntimamente con la vida de la ciudad. (Canalejas, 1874-1876, t. II, p. XIX).

\section{Conclusiones}

Creo haber mostrado que, en el pensamiento de Canalejas, las circunstancias políticas y las corrientes ideológicas (surgimiento del estado liberal, difusión del krausopositivismo) concurren con el pensamiento y liberal, y todo ello da lugar a una perspectiva antidogmática y crítica que conduce al sincretismo. No solo la tradición historiográfica sobre la Literatura Latina, sino también su ideología liberal convierten al autor en heredero directo del pensamiento ilustrado, favoreciendo en su obra una síntesis peculiar.

En efecto, la obra de Canalejas se inserta en la tradición inmediata, pero no se queda, sin embargo, anclada en ella, sino que sabe acomodarse a los adelantos de su época y aun servirse de ellos para avanzar. Precisamente, su sólida integración en 
una tradición bien reconocible contribuye a destacar aun más los cambios que resultan de su posición personal, que maneja con prudencia y autoconciencia de estos.

Canalejas se formó en la tradición de la filología comparada y está muy influido también por el pensamiento idealista dieciochesco. No obstante, su actitud antidogmática le permitió integrar positivismo e idealismo para conformar un pensamiento que en ocasiones recuerda al Pidal de la primera época. Y creo que ello nos permite vislumbrar una matriz común de lo que luego sería la escuela de filología española.

Ciertamente, en sus orígenes la historiografía de la literatura latina ha tenido un carácter ancilar respecto de otras disciplinas, como señala García Jurado (2008b, 184). Pero si esto es cierto, no lo es menos que su contribución a la historiografía moderna de la literatura española ha sido importante. Siendo así, no parece aventurado afirmar que su contribución a la conformación de la escuela de filología española también ha podido ser significativa. Y nuestro análisis al menos no contradice esta hipótesis, sino que la avalora.

Obra notable por extensión, profundidad y rigor y por su atención al pensamiento y las corrientes de la época y la inserción en una tradición que sin embargo sabe trascender, los Apuntes revelan una aguda conciencia metodológica y epistemológica. No constituyen, ni mucho menos, una obra historiográficamente ingenua, sino un trabajo muy destacado y adelantado a su tiempo.

\section{Referencias bibliográficas}

\section{Fuentes primarias}

Camús, A. A. (ed.) (1842). Compendio de Historia Universal., Madrid: Boix.

Camús, A. A. (1846). Preceptistas latinos para el uso de las clases de Principios de Retórica y Poética. Madrid: estereotipia de M. Rivadeneyra.

Camús, A. A. (1847). Curso elemental de retórica y poética. Retórica de Hugo Blair. Poética de Sánchez. Madrid: Imprenta de la Publicidad, a cargo de M. Rivadeneyra.

Camús, A. A. (1864). Programa de literatura clásica griega y latina. Madrid: Imprenta de las Escuelas Pías.

Mayáns y Siscar, G. (1777-1778). P. Virgilii Maronis opera omnia variis interpretibus et notis illustrata. José Tomás y Orga, 5 v. Reimpresa en Valencia en 1995: Vida de Publio Virgilio Maron, Hermanos de Orga.

Mayone y del Mazo, F (871). Apuntes de las explicaciones de literatura latina del catedrático de esta asignatura en la Universidad Central Alfredo Adolfo Camús. Ms conservado en la Biblioteca de la Universidad Complutense de Madrid, signatura: BH FLL 49834. Disponible en http://dioscorides.ucm.es/proyecto_digitalizacion/index.php?5312771589 [Consulta: 06/05/2019].

Canalejas Méndez, J. (1873). Programa de un curso de Principios Generales de Literatura explicado en la Universidad Central [...] 1872 a 1873, Madrid, imprenta fundición y Estenotipia de D. Juan Aguado, 1873. Disponible en la Biblioteca Digital Hispánica: http:// bdh-rd.bne.es/viewer.vm?id=0000202012\&page $=1$ [Consulta: 22/03/2020).

Canalejas Méndez, José (1874-1876). Apuntes para un curso de literatura latina, Madrid, Establecimiento tipográfico de Manuel Martínez, 1874 (t. I) y 1876 (t. II).

Menéndez y Pelayo, M. (1950-1953). Bibliografía Hispano-Latina clásica. Madrid: CSIC, $10 \mathrm{v}$. 
Pérez Galdós, B. Apuntes de Literatura latina según las explicaciones del Dr. Dn. Alfredo Adolfo Camús, catedrático de esta asignatura en la Universidad Central. Ms. Conservado en la casa Museo Pérez Galdós en Las Palmas de Gran Canaria. Corresponden al curso 1862-1863.

Rodríguez Mohedano, P. y R. (1781). Historia literaria de España. Madrid: Ibarra, t. VII.

\section{Funtes secundarias}

Abellán, J. L. (1979). 1979 Historia crítica del pensamiento español. 8 vols. Barcelona: Círculo de Lectores, 1992.

Alvarado, M. (2009). Paratexto. Buenos Aires: Eudeba.

Christmann, H. H. (1985). Filología idealista y lingüística moderna. Madrid: Gredos.

Espino, Javier (2003). «Política y enseñanza del latín: liberales y conservadores en la gramática latina durante el reinado de Fernando VII», Estudios clásicos, 123, pp. 45-65.

Espino, Javier (2010). «Vicente García de Diego y la renovación de la gramática latina», Analecta Malacitana, Anejo LXXVIII, pp. 113-136.

Fernández Corte, J. C. (2004). «La invención de al Historia de la literatura Latina en España (y una breve reflexión sobre Europa)», Cuadernos de Filología Clásica, Estudios latinos, 24, núm. 1, 95-113.

Garatea Grau, C. (2005). El problema del cambio lingüistico en ramón Menéndez Pidal. El individuo, la tradición y la historia. Tubingen: Gunter Narr Verlag.

García Camarero E. y E. (1970). La polémica de la ciencia española, Madrid: Alianza Editorial.

García Jurado, F. (2004). «La historiografía de la literatura latina y su conciencia en los autores modernos: visiones divergentes del canon y la decadencia en Pérez Galdós y Huysmans», Cuadernos de Filología Clásica: Estudios Latinos, 24/1, 115-147.

García Jurado, F. (2005a). «Los primeros manuales de literatura latina en España (18461866): aproximación a la historiografía literaria», en Antonio Alvar Ezquerra (coord.), Actas del XI Congreso Español de Estudios Clásicos, Vol. 3, 669-678.

García Jurado, F. (ed.) (2005b). «La historia de la literatura grecolatina en el siglo XIX español: espacio social y literario». Analecta Malacitana, anejo LI, Málaga: Universidad.

García Jurado, F. (2007). «Virgilio y la Ilustración. Mayáns, o los fundamentos críticos de la Tradición Literaria en España», Revista de Historiografía (RevHis), N. ${ }^{\circ}$ 7, pp. 96-110.

García Jurado, F. (2008a). «Canalejas, historiador de la literatura latina», Revista de historiografía, 9, V (2/2008), 167-179.

García Jurado, F. (2008b). «Ensayo de una Historiografía de la Literatura Latina en España (1778-1936)», Revista de Estudios Latinos, 8, 179-2001.

Genette, Gérard (1989). Palimpsestos. La literatura de segundo grado. Celia Fernández Prieto (trad.) Madrid: Taurus.

Koerner, E. K. K. (1996). «Problemas persistentes de la historiografía lingüística», Analecta malacitana: Revista de la Sección de Filología de la Facultad de Filosofía y Letras, 19/1, 41-66

Laborda Gil, X. (1981). Racionalismo y empirismo en la lingüistica del siglo XVII: Port-Royal y Wilkins Disponible en: https://www.tdx.cat/handle/10803/1727 [Consulta: 17/06/2019]. Es la tesis doctoral de su autor, defendida en la Universidad de Barcelona en 1981.

Ladero Quesada, M. Á. (1996). «1996 "La Decadencia española. Historia de un tópico» Historia 16, n. $^{\circ} 238,33-52$; n. ${ }^{\circ} 239$, pp. 26-42. 
Menéndez y Pelayo, M. (1950-1953 [1902]). Bibliografía Hispano-Latina clásica. Madrid: CSIC, $10 \mathrm{v}$.

Munteanu Colán, D. (2017). Breve historia de la lingüística románica. Madrid: Arco Libros-LA MURALLA.

Núñez Gonzalez, Juan M. a (1991). «Ciceronianismo y latín renacentista», Minerva: Revista de filología clásica, $\mathrm{N}^{\mathrm{0}}$ 5, pp. 229-258

Núñez Gonzalez, Juan M.a (1993). El ciceronianismo en España. Valladolid: Universidad.

Perdomo-Batista, Miguel Á. (2011). «El enfrentamiento de Mayáns y los Iriarte a propósito de las gramáticas latinas», Cuadernos de Filología Clásica. Estudios Latinos, 31, núm. 2, 355-388. DOI: https://doi.org/10.5209/rev_CFCL.2011.v31.n2.38064

Perdomo-Batista, Miguel Á. (2013). «Propuestas para una historiografía de la lingüística de base hermenéutica», Revista de Filología de la Universidad de La Laguna, 31, 125-140.

Perdomo-Batista, Miguel Á. (2016) «La perspectiva discursiva en la historiografía de la lingüística: el argumento de la decadencia como estrategia de legitimación en las obras del siglo XVIII», en La historiografía lingüística como paradigma de investigación, Visor, 591-608.

Perdomo-Batista, Miguel Á. (2020). «Entre la modernidad y la tradición: la idea de filología en España en el siglo XVIII», Cuadernos de Estudios del Siglo XVIII, 30, Monográfico Los campos del saber en el siglo XVIII (en prensa).

Portolés, J. (1986). Medio siglo de filología española (1896-1952). Positivismo e idealismo, Madrid, Cátedra.

Sáinz Rodríguez, P. (1962). Evolución de las ideas sobre la decadencia española y otros estudios de crítica literaria. Madrid: Ediciones Rialp.

Salvador Gimeno, M. (2015-2016). Introducción a los apuntes de las explicaciones de literatura latina del catedrático de esta asignatura en la universidad central Dr. D. Alfredo Adolfo Camús, pertenecientes a Francisco Mayone y del Mazo. Trabajo dirigido por Francisco García Jurado, para el Máster en Filología Clásica, UCM, 2015-2016. Repositorio de la UCM. Disponible en https://eprints.ucm.es/39269/1/apuntes\%20de\%20 canalejas.pdf [Consulta: 12/05/2019].

Swiggers, P. (2009). «La historiografía de la lingüística: apuntes y reflexiones», RAHL: Revista argentina de historiografía lingüistica, 1/1, 67-76.

Valle López, A. del (1990). La Universidad Central y su distrito en el primer decenio de la Restauración Borbónica. Madrid: Consejo de Universidades.

Valls, R. (1997-1998). «Los manuales escolares españoles de Historia», Educació i Història, 3, 120-130. 